Biol. Stud. 2018: 12(3-4); 55-62 • DOI: https://doi.org/10.30970/sbi.1203.576

www.http://publications.Inu.edu.ua/journals/index.php/biology

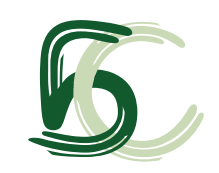

UDC $581.1: 631.811: 546.173$

\title{
INFLUENCE OF TRIACONTANOL ON MORPHOMETRIC PARAMETERS AND NITRATE CONTENT IN HELIANTHUS ANNUS L. AND CUCUMIS SATIVUS L. SEEDLINGS
}

\author{
V. Baranov, S. Tehlivets* \\ Ivan Franko National University of Lviv, 4, Hrushevskyi St., Lviv 79005, Ukraine \\ *Corresponding author: e-mail: steptehl@gmail.com
}

Baranov V., Tehlivets S. Influence of triacontanol on morphometric parameters and nitrate content in Helianthus annus L. and Cucumis sativus L. seedling. Studia Biologica, 2018: 12(3-4); 55-62 - DOI: https://doi.org/10.30970/sbi.1203.576

Studying of plant growth stimulants is an important task for scientists. Triacontanol $\mathrm{H}_{3} \mathrm{C}\left(\mathrm{CH}_{2}\right)_{28} \mathrm{CH}_{2} \mathrm{OH}$ is a fatty alcohol, also known as melicylic alcohol or myricyl alcohol found in cuticular waxes of plants, and is a part of beeswax. Triacontanol was first discovered as a component of alfalfa cuticular wax Medicago sativa L. Study of the biological activity of this alcohol began in the last century and continues in different countries. Industrial produced triacontinol sample obtained from the beeswax contains impurities of other fatty alcohols that can neutralize the effect of the triacontanol. Study of the industrial produced triacontanol sample from Huzhou Sifeng Biochem Co.Ltd, China on growth and content of nitrates in sunflower and cucumber seedlings was conducted. In the industrial produced triakontanol used in our experiments, the composition of alcohols was as follows: triacontanol $95.6 \%$, dotirancontanol $1.9 \%$, octacosanol $1.3 \%$, nonaccosanol $0.38 \%$, and the rest (less than $0.5 \%$ ) belong to heptacosanol and hexacosanol. Our studies have shown that the preparation at a concentration of $1 \mathrm{mg} / \mathrm{L}$ increases morphometric indices of sunflower seedlings and cucumbers, while the concentration of $25 \mathrm{mg} / \mathrm{L}$ reduces them, and the concentration of $10 \mathrm{mg} / \mathrm{L}$ is almost unaffected. With an increase of triacontanol concentration the content of nitrates decreased in both types of seedlings (however, within the statistical error), which may be explained by an increase in the intensity of the use of nitrates. Concomitant alcohols available in the industrial produced triacontanol sample, practically haven't any effect. In our opinion, triacontanol can be applied in crop production to increase plant growth. Concentration of $1 \mathrm{mg} / \mathrm{L}$ is the most effective, and therefore, available for use in agriculture, as

(ㄷ 2018 V. Baranov et al.; Published by the Ivan Franko National University of Lviv on behalf of Біологічні Студії / Studia Biologica. This is an Open Access article distributed under the terms of the Creative Commons Attribution License (http://www.budapestopenaccessinitiative.org/ and Creative Commons Attribution 4.0 License), which permits unrestricted reuse, distribution, and reproduction in any medium, provided the original work is properly cited.

ISSN 1996-4536 (print) • ISSN 2311-0783 (on-line) • Біологічні Студії / Studia Biologica • 2018 • Том 12/№3-4 • С. 55-62 
well as for cultivation the of medicinal plants. Consequently, the use of triacontanol is an effective way to increase the size of plant seedlings, that may result in an increase in the yield of these plants.

Keywords: triacontanol, plant growth, nitrates, Cucumis sativus L., Helianthus annus L.

\section{INTRODUCTION}

Triacontanol $\mathrm{H}_{3} \mathrm{C}\left(\mathrm{CH}_{2}\right)_{28} \mathrm{CH}_{2} \mathrm{OH}$ is a fatty alcohol which contains 30 carbon atoms. Triacontanol was first discovered as a component of alfalfa cuticular wax Medicago sativa L. in 1983 [2], and nowadays is one of the methods of its extraction from beeswax [6]. Subsequently, it was found in other plants. In wheat, its contents is $3 \%$ of all free alcohols, among those found in leaf waxes [18]. It stimulates nitrogen fixation, enzyme activity, photosynthesis, absorption of mineral elements, the use of mineral elements, gene regulation, membrane stability and productivity of many crops $[17,12,15]$. There is evidence that exogenous triacontanol treatment increases the yield of such economically important plants as rice (Oryza sativa L.), wheat (Triticurn aesitivum L.), tomatoes (Lycopersicon esculentum Mill.), Common mushrooms [Vigna radiata (L.) Wilczek], corn (Zea mays L.) and hyacinth beans (Lablab purpureus L.) [8].

Also, triacontanol has a synergistic effect with the gibberellic acid shown to increase in content of the essential oils, a mass of 1000 seeds, and the number of flowers in the coriander umbrella (Coriandrum sativum L.) and the number of umbrellas per plant [14]. The same effect of triacontanol was obtained in a study conducted in 2014 [13].

Information on the effect of the triacontanol on plant metabolism was actively investigated in the twentieth century. The effect of the triacontanol on dry weight of plants [10, $3]$, the content of amino acids and proteins [9], $\mathrm{CO}_{2}$ fixation activity [5] and an increase in the intensity of carbon dioxide fixation, reduction activity of photobreathing, increase of dry mass of plants. The influence on wheat, maize and rice was most actively investigated, but little is known about its impact on other important agricultural crops. Also, plant growth stimulators can improve stress resistance of plant [11]. Unfortunately, in Ukraine, and earlier in the former USSR, there aren't a lot of investigations related to the effects of the triacontanol on plants.

In addition, it is known that the concomitant alcohols can neutralize the action of the triacontanol [7]. In the industrial produced triacontanol sample used in our experiments, the composition of alcohol was as follows: triocontinol $95.6 \%$, dotriancontanol $1.9 \%$, octacosanol $1.3 \%$, nonacosanol $0.38 \%$, and the rest belonged to heptacosanol and hexacosanol. Thus, the purpose of our work was to determine which changes occur after exogenous treating with this industrial produced triacontanol sample in the presence of the impurities of accompanying alcohols, in sunflower and cucumbers seedlings, and whether this industrial produced triacontanol sample will have a positive effect on growth and content of nitrates in seedlings.

\section{MATERIALS AND METHODS}

95\% Triacontonol was provided by Huzhou Sifeng Biochem Co.Ltd, China to which we express our sincere gratitude. Since the triacontanol is insoluble in water, it was

ISSN 1996-4536 (print) • ISSN 2311-0783 (on-line) • Біологічні Студії / Studia Biologica • 2018 • Том 12/№3-4 • С. 55-62 
dissolved in a concentration of $25 \mathrm{mg} / \mathrm{L}$ with $0.5 \mathrm{ml}$ of Tween-20 in $100 \mathrm{ml}$ of distilled water and heated to dissolve. After that, they were poured into a flask for $1 \mathrm{~L}$ and filled with a distillate. Other concentrations were prepared by dilution with water. To determine the effect of the triacontanol on the morphometric parameters of seedlings of plants, seeds were sprouted in Petri dishes on solutions of triacontanol in concentrations of 1 , 10 and $25 \mathrm{mg} / \mathrm{L}$ for 7 days, in a dark thermostat with a temperature of $22^{\circ} \mathrm{C} .10$ seeds were placed in each Petri dish, the experiment was carried out in triple repetition [4]. The determination of the content of nitrates was carried out in plants grown in pots on the garden soil, and sprayed with the triacontanol solution. Control was sprayed by the distillate, the spraying was carried out from 7 days after the day landing the seeds in the soil and spraying was repeated every three days for 4 weeks. The content of nitrates was determined using a technique with the Griss reagent [16]. The results were calculated in "Statist" software.

\section{RESULTS AND DISCUSSION}

The first stage of the research was to determine the effect of triacontanol on morphometric parameters of sunflower and cucumbers seedlings (Fig.1-4).

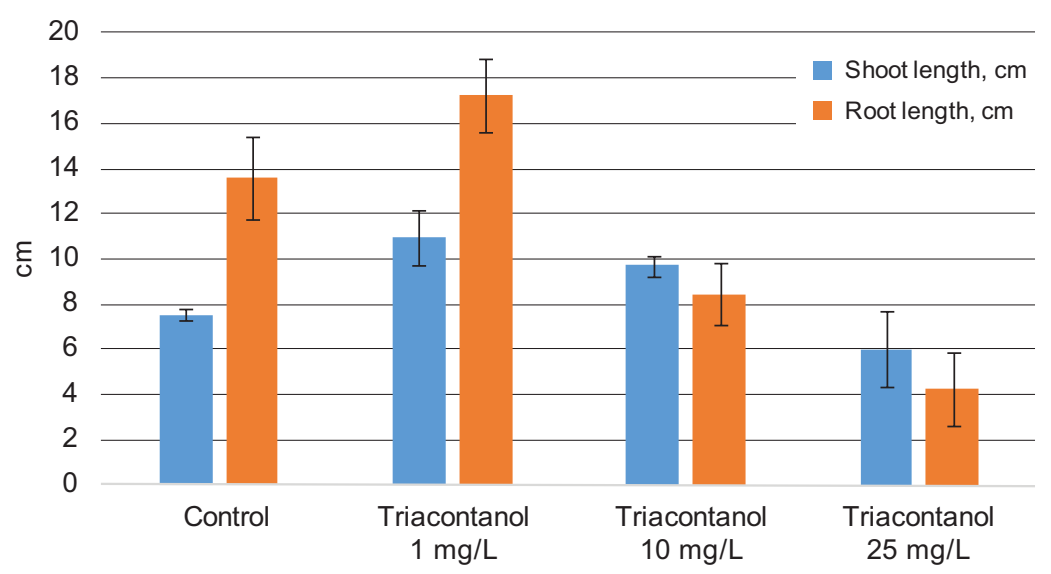

Fig. 1. The effect of triacontanol solution on the length of shoots and roots of sunflower

Рис. 1. Вплив тріаконтанолу на довжину пагонів і коренів соняшника

As shown in Fig. 1, triacontanol at a concentration of $1 \mathrm{mg} / \mathrm{L}$ increased the length of the shoots and sunflower roots, and the concentration of $25 \mathrm{mg} / \mathrm{L}$ reduced both parameters. At the same time, the concentration of $10 \mathrm{mg} / \mathrm{L}$ did not cause any changes.

The use of triacontanol at concentrations of 1 and $10 \mathrm{mg} / \mathrm{L}$ increased the weight of the root and shoot of sunflower, and the concentration of $25 \mathrm{mg} / \mathrm{L}$ reduced these parameters, similar to the effect of this concentration on the length of the roots and shoots.

In the seedlings of cucumber, the same trend as in the seedlings of sunflower - the concentration of $1 \mathrm{mg} / \mathrm{L}$ increased the length of the shoots and slightly increased the length of the root, the concentration of $10 \mathrm{mg} / \mathrm{L}$ almost did not affect these indicators, and the concentration of $25 \mathrm{mg} / \mathrm{L}$ reduced them.

The triacontanol had a similar effect on the mass of roots and shoots of cucumber as on the length of shoots and roots. A use of triacontanol at the concentration of $1 \mathrm{mg} / \mathrm{L}$

ISSN 1996-4536 (print) • ISSN 2311-0783 (on-line) • Біологічні Студії / Studia Biologica • 2018 • Том 12/№3-4 • С. 55-62 
increased the weight of the root and shoots of sunflower, and the concentration of $25 \mathrm{mg} / \mathrm{L}$ reduced these parameters. Concentration of $10 \mathrm{mg} / \mathrm{L}$ did not affect them.

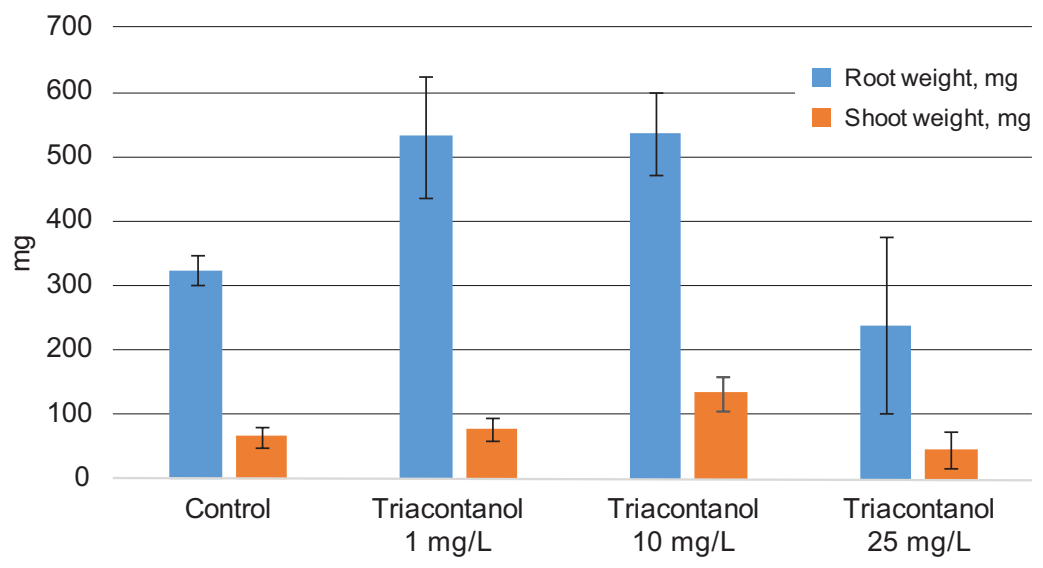

Fig. 2. The effect of triacontanol on the weight of the root and shoots of sunflower

Рис. 2. Вплив тріаконтанолу на масу пагонів і коренів соняшника

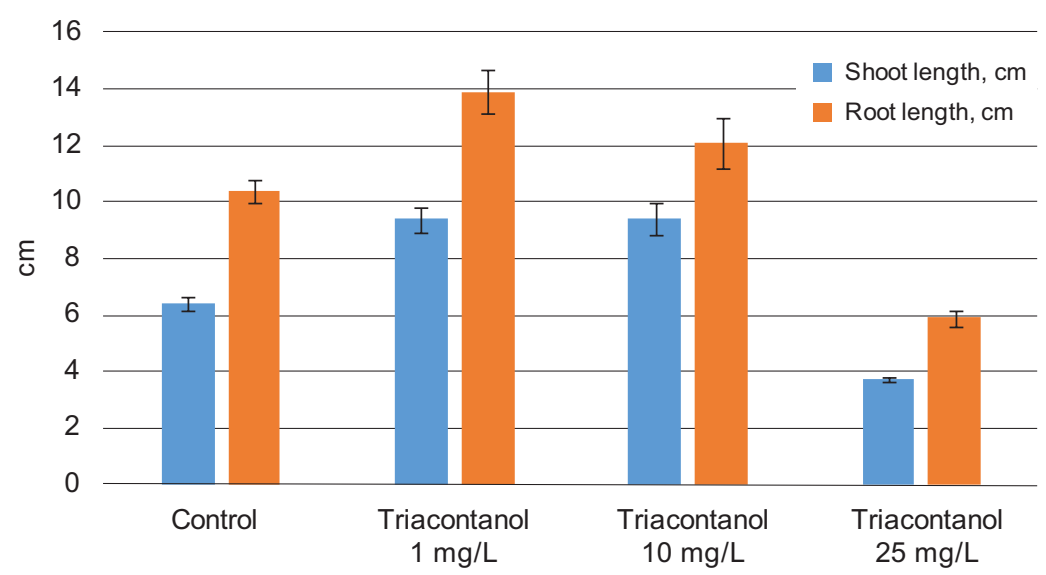

Fig. 3. The influence of triacontanol solution on the length of shoots and roots of cucumber

Рис. 3. Вплив тріаконтанолу на довжину пагонів і коренів огірка

It is known that in early stages of development, when young plants are poor in carbohydrates, it is better to absorb the nitrates, because for the assimilation of ammonia it is needed organic acids, which are formed from carbohydrates which are needed to normal growth of seedling. So, the next stage of our study was to evaluate in the content of nitrates.

Spraying with a solution of triacontanol at first glance reduced the content of nitrates in all variants and in all plants, although the statistical error overrides this decrease, possibly due to a small number of repetitions that will be re-tested in field conditions. 


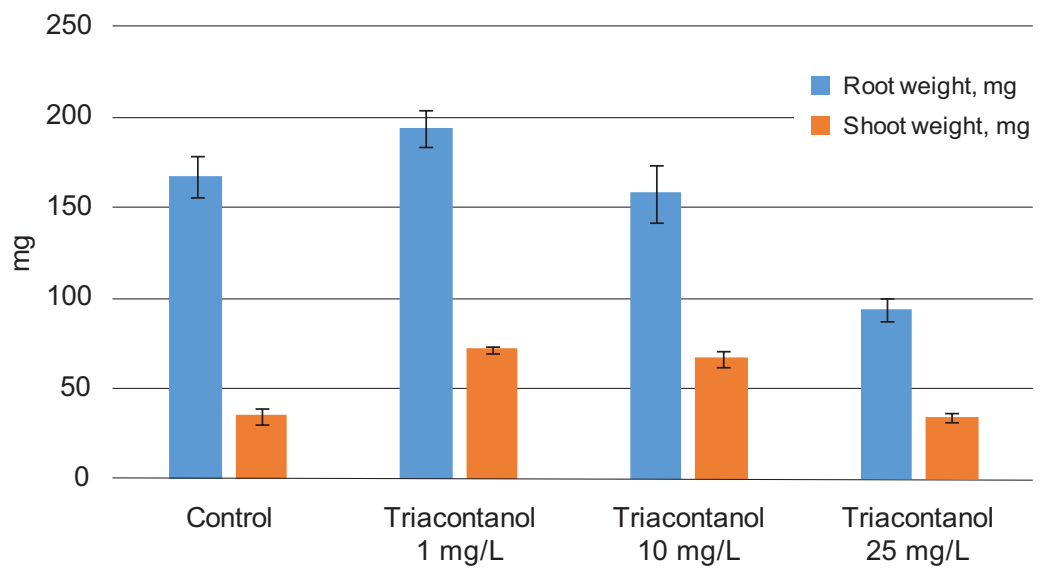

Fig. 4. The effect of triacontanol on the weight of root and shoots of cucumber

Рис. 4. Вплив тріаконтанолу на масу пагонів і коренів огірка

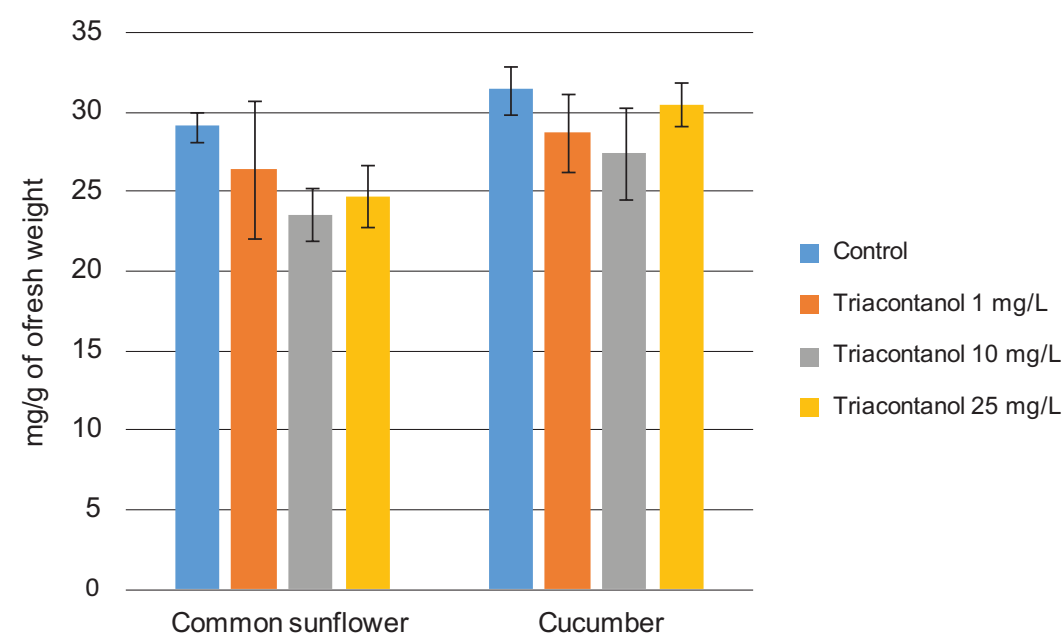

Fig. 5. The influence of triacontanol on the content of nitrates in shoots of plants

Рис. 5. Вплив тріаконтанолу на вміст нітратів у проростках рослин

\section{CONCLUSIONS}

Low concentrations of triacontanol in seedlings treatment of sunflower and cucumber stimulated the utilization of nitrates, and high concentrations inhibited that process which will be re-tested in field conditions. The effect of optimal concentrations of triacontanol which stimulate growth of sunflower seedlings and cucumbers were accompanied by changes in the content of nitrates. Consequently, it can be assumed that treating with triacontanol can enhance growth by accelerating the utilization of nitrates and possibly by increasing a productivity of plants, as shown in iterature [1]. Since most effective dose of the triacontanol for sunflowers and cucumbers is $1 \mathrm{mg} / \mathrm{L}$, its use will 
not be vere expensive, that will stimulate its use. Concomitant alcohols available in the industrial produced triacontanol, practically have no effect on studied parameters.

1. Aftab T., Khan M., Idrees M., M. Naeem et al. Stimulation of crop productivity, photosynthesis and artemisinin production in Artemisia annua L. by triacontanol and gibberellic acid application. Journal of Plant Interactions, 2010; 5(4): 273-281.

[DOI: https://doi.org/10.1080/17429141003647137]

2. Dolotovskaia L.Z., Krutko V.M. Triacontanol as growth regulator. Agrochemistry, 1992; 7: 138-144. (In Russian).

3. Eriksen A.B., Haugstad M.K., Nilsen S. Yield of tomato and maize in response to foliar and root applications of triacontanol. Plant Growth Reg, 1982; 1: 11-14. [DOI: https://doi.org/10.1007/BF00024217]

4. GOST 1203884. Methods for determining the germination and germination energy. Seeds of agricultural crops. Publishing Standards. Moscow, 1984; 1: 57 p. (In Russian).

5. Ivanov A.G., Angelov M.N. Photosynthesis response to triacontanol correlates with increased dynamics of mezophyll protoplast and chloroplast membranes. Plant Growth. Reg, 1997; 21: $145-152$.

[DOI: https://doi.org/10.1023/A:1005790121111]

6. Jackson M.A., Eller F.J. Isolation of long-chain aliphatic alcohols from beeswax using lipase-catalyzed methanolysis in supercritical carbon dioxide. The Journal of Supercritical Fluids, 2006; 37(2): 173-177.

[DOI: https://doi.org/10.1016/j.supflu.2005.08.008]

7. Jones J., Wert V., Ries S. Specificity of 1-triacontanol as a plant growth stimulator and inhibition of its effect by other long-chain compounds. Planta, 1979; 144(3); 277-228. [DOI: https://doi.org/10.1007/BF00388770]

8. Khan M.M.A., M. Mujibur-Rahman, M. Naeem, F. Mohammad, M.H. Siddiqui, M.N. Khan. Triacontanol-induced changes in the growth, yield and quality of tomato (Lycopersicon esculentum Mill). Electron. J. Environ. Agric Food Chem, 2006; 5: 1492-1499.

9. Kissimon I., Tantos A., Miscellaneous A. et al Stress alternations in growth parameters, pigment content and photosynthetic functions of in vivo cultured plants. Z. Naturforsch, 1999; 54: 834-839.

[DOI: https://doi.org/10.1515/znc-1999-9-1033]

10. Knowles N.R., Ries S.K. Rapid growth and apparent total nitrogen increases in rice and corn plants following applications of triacontanol. Plant Physiol, 1981; 68: 1279-1284. [DOI: https://doi.org/10.1104/pp.68.6.1279]

11. Makogonenko S.Yu., Baranov V.I., Terek O.I. The influence of the regoplant and stimpo on the activity of antioxidant protection enzumes in the Helianthus annus L. and Brassica napus L. growth on the substrations of the wet recovery of coal mine. Studia Biologica, 2018; 12(1): 47-54.

[DOI: https://doi.org/10.30970/sbi.1201.539]

12. Malik, M., R.D. Williams. Allelopathic growth stimulation of plants and microorganisms. Allelopathy J, 2005; 16: 175-198.

[Google Scholar]

13. Meena S. K., Jat N. L., Sharma B., Meena V. S. Effect of Plant growth regulators and sulphur on productivity of coriander (Coriandrum sativum L.) in Rajasthan. The Bioscan, 2014; 6 : 69-73. [Google Scholar]

14. Naeem M., Khan A., Aftab T. Synergistic Effects of Gibberelic Acid and Triacontanol on growth, physiology, enzyme activities and essential oil content of Coriandrum sativum L. The

ISSN 1996-4536 (print) • ISSN 2311-0783 (on-line) • Біологічні Студії / Studia Biologica • 2018 • Том 12/№3-4 • С. 55-62 
Asian and Australasian Journal of Plant Science and Biotechnology Global Science books, 2010, P. 24-29.

[Google Scholar]

15. Naeem M., M.M.A Khan, Moinuddin, M.H. Siddiqui Triacontanol stimulates nitrogen fixation, enzyme activity, photosynthesis, crop productivity and quality of hyacinth bean (Lablab purpureus L.) Sci. Hortic, 2009; 121: 389-396.

[DOI: https://doi.org/10.1016/j.scienta.2009.02.030]

16. Pochinok H.N. Methods of biochemical analisys of plants. Kyiv: Science thought, 1975. 96 p. (In Russian).

17. Ries S.K. Regulation of plant growth with triacontanol. CRC Crit Rev. Plant Sci, 1985; 2: 239-285.

[DOI: 10.1080/07352688509382197]

18. Tulloch A.P., L.L. Hoffman. Epicuticular waxes of secale cereal and triticale hexaploid leaves.

Phytochem, 1974; 13: 2535-2540.

[DOI: https://doi.org/10.1016/s0031-9422(00)86932-0]

\title{
ВПЛИВ ТРІАКОНТАНОЛУ НА МОРФОМЕТРИЧНІ ПОКАЗНИКИ TA BMICT HITPATIB У ПPOPOCTKAX HELIANTHUS ANNUS L. I CUCUMIS SATIVUS L.
}

\author{
В. Баранов, С. Теглівець \\ Львівський національний університет імені Івана Франка \\ вул. Грушевського 4, Львів 79005, Україна \\ e-mail: steptehl@gmail.com
}

Вивчення стимуляторів росту рослин є важливим завданням для вчених усього світу. Тріаконтанол - це жирний спирт, також відомий як меліциловий або мірициловий спирт, який трапляється в кутикулярних восках рослин, а також є частиною бджолиного воску. Його структурна формула $\mathrm{H}_{3} \mathrm{C}\left(\mathrm{CH}_{2}\right)_{28} \mathrm{CH}_{2} \mathrm{OH}$. Тріаконтанол уперше був виявлений як компонент лікарського воску Cucticular Medicago sativa L. Вивчення біологічної активності цієї сполуки почалось у минулому столітті і триває у різних країнах на сьогодні. Промислові препарати тріаконтанолу отримані з бджолиного воску, містять домішки інших жирних спиртів, які можуть нейтралізувати вплив тріаконтанолу. Тому було проведено дослідження тріаконтанолу промислового виробництва, отриманого від компанії Huzhou Sifeng Biochem Co.Ltd, Китай для визначення його впливу на ростові показники та вміст нітратів у проростках соняшника й огірків. У промисловому препараті тріаконтанолу, що використовувався в наших дослідах склад спиртів був таким: тріаконтанол 95,6 \%, дотріаконтанол 1.9 \%, октакозанол 1,3 \%, нонакозанол 0,38 \%, решта (менше 0,5 \%) припадала на гептакозанол і гексакозанол. У ході наших досліджень встановлено, що препарат у концентрації 1 мг/л збільшує морфометричні показники проростків огірків і соняшника, концентрація 10 мг/л майже не впливає, тоді як концентрація 25 мг/л зменшує їх. Зі збільшенням концентрації тріаконтанолу вміст нітратів знижувався у обох видів проростків (однак у межах статистичної похибки), що, можливо, пояснюється зниженням інтенсивності використання нітратів. Таким чином, суміжні спирти, наявні у промисловому зразку тріаконтанолу, практично не

ISSN 1996-4536 (print) • ISSN 2311-0783 (on-line) • Біологічні Студії / Studia Biologica • 2018 • Том 12/№3-4 • С. 55-62 
впливали на його дію. Цей промисловий препарат тріаконтанолу можна застосовувати у рослинництві для прискорення росту рослин. Використання концентрації $1 \mathrm{мг/л} є$ ефрективнішим, а отже, доступним для застосування у сільському господарстві, а також для вирощування лікарських рослин. Отже, на нашу думку, використання тріаконтанолу $\epsilon$ ефективним способом збільшення розмірів проростків рослин, що може привести до збільшення вегетативної маси рослин.

Ключові слова: тріаконтанол, ріст рослин, нітрати, Cucumis sativus L., Helianthus annus L.

Одержано: 07.12.2018

ISSN 1996-4536 (print) • ISSN 2311-0783 (on-line) • Біологічні Студії / Studia Biologica • 2018 • Том 12/№3-4 • С. 55-62 